\title{
Unearthing Neanderthal population history using nuclear and mitochondrial DNA from cave sediments
}

\author{
Benjamin Vernot', Elena I. Zavala', Asier Gómez-Olivencia ${ }^{2,3,4}$, Zenobia Jacobs $^{5,6}$, Viviane Slon ${ }^{1,7,8}$, \\ Fabrizio Mafessoni', Frédéric Romagné ${ }^{1}$, Alice Pearson', Martin Petr', Nohemi Sala ${ }^{4,9}$, Adrián Pablos ${ }^{4,9}$, \\ Arantza Aranburu' ${ }^{2,3}$, José María Bermúdez de Castro ${ }^{9}$, Eudald Carbonell ${ }^{10,11}$, Bo Li ${ }^{5,6}$, Maciej T. Krajcarz ${ }^{12}$, \\ Andrey I. Krivoshapkin ${ }^{13,14}$, Kseniya A. Kolobova ${ }^{13}$, Maxim B. Kozlikin ${ }^{13}$, Michael V. Shunkov ${ }^{13}$,

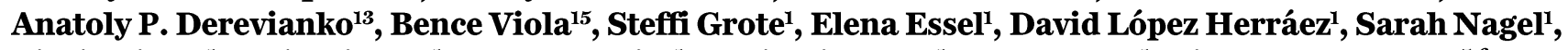 \\ Birgit Nickel', Julia Richter ${ }^{1}$, Anna Schmidt', Benjamin Peter', Janet Kelso' ${ }^{1}$, Richard G. Roberts ${ }^{5,6}$, \\ Juan-Luis Arsuaga ${ }^{4,16}$, Matthias Meyer*
}

\begin{abstract}
1Department of Evolutionary Genetics, Max-Planck-Institute for Evolutionary Anthropology, Leipzig, Germany. 2Departamento de Geología, Facultad de Ciencia y Tecnología, Universidad del País Vasco-Euskal Herriko Unibertsitatea (UPV/EHU), Leioa, Spain. ${ }^{3}$ Sociedad de Ciencias Aranzadi, Donostia-San Sebastián, Spain. ${ }^{4}$ Centro Mixto UCMISCIII de Evolución y Comportamiento Humanos, Madrid, Spain. ${ }^{5}$ Centre for Archaeological Science, School of Earth, Atmospheric and Life Sciences, University of Wollongong, Wollongong, New South Wales, Australia. ${ }^{6}$ Australian Research Council (ARC) Centre of Excellence for Australian Biodiversity and Heritage, University of Wollongong, Wollongong, New South Wales, Australia. ${ }^{7}$ Department of Anatomy and Anthropology and Department of Human Molecular Genetics and Biochemistry, Sackler Faculty of Medicine, Tel Aviv University, Tel Aviv, Israel. ${ }^{8}$ The Dan David Center for Human Evolution and Biohistory Research, Tel Aviv University, 6997801 Tel Aviv, Israel.

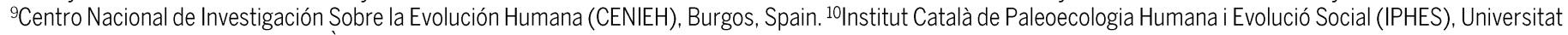
Rovira i Virgili, Tarragona, Spain. ${ }^{11}$ Àrea de Prehistòria, Universitat Rovira i Virgili, Tarragona, Spain. ${ }^{12}$ Institute of Geological Sciences, Polish Academy of Sciences, Warszawa, Poland. ${ }^{13}$ Institute of Archaeology and Ethnography, Russian Academy of Sciences, Novosibirsk, Russia. ${ }^{14}$ Novosibirsk State University, Novosibirsk, Russia. ${ }^{15}$ Department of Anthropology, University of Toronto, Toronto, Ontario, Canada. ${ }^{16}$ Departamento de Paleontología, Facultad Ciencias Geológicas, Universidad Complutense de Madrid, Madrid, Spain.

*Corresponding author. Email: benjamin_vernot@eva.mpg.de (B.V.); mmeyer@eva.mpg.de (M.M.)
\end{abstract}

Bones and teeth are important sources of Pleistocene hominin DNA, but are rarely recovered at archaeological sites. Mitochondrial DNA has been retrieved from cave sediments, but provides limited value for studying population relationships. We therefore developed methods for the enrichment and analysis of nuclear DNA from sediments, and applied them to cave deposits in western Europe and southern Siberia dated to between approximately 200,000 and 50,000 years ago. We detect a population replacement in northern Spain approximately 100,000 years ago, accompanied by a turnover of mitochondrial DNA. We also identify two radiation events in Neanderthal history during the early part of the Late Pleistocene. Our work lays the ground for studying the population history of ancient hominins from trace amounts of nuclear DNA in sediments.

The analysis of ancient DNA from Pleistocene hominins has greatly enhanced our understanding of the evolutionary history of archaic humans, and their interactions with early modern humans. To date, complete or partial nuclear genome sequences have been recovered from the skeletal remains of 23 archaic hominin individuals: 18 Neanderthals from 14 sites across Eurasia (mostly in Europe), four Denisovans, and the offspring of a Neanderthal mother and a Denisovan father (Denisova 11) (1) recovered from Denisova Cave in the Altai Mountains of southern Siberia. Although numerous Paleolithic sites have been excavated, relatively few have yielded skeletal remains of hominins, which are often concentrated in one or a few strata. Attempts to reconstruct the genetic history of archaic hominins are therefore constrained by an uneven temporal and spatial sampling, limited largely by the availability of specimens.

In 2017, it was found that hominin mitochondrial DNA (mtDNA) can be recovered from Pleistocene sediments (2), indicating that it may be possible to overcome the dependency on the scarce fossil record in the quest for hominin DNA. However, mtDNA only carries information about the maternal lineage and does not always reflect the complete population history [e.g., (3)]. Nuclear DNA contains far more information, but its retrieval from sediments presents substantial challenges: it is present in fewer copies than mtDNA, and many loci are not informative for population genetic analyses. Additionally, the vast majority of mammalian DNA in sediments is non-hominin, which may be difficult to distinguish from hominin DNA due to sequence homology at many loci. These characteristics, as well as the dominance of microbial DNA (2), hamper attempts to retrieve nuclear sequences in sufficient number and quality for population genetic analyses by simple shotgun sequencing. To overcome these challenges, we set out to retrieve hominin nuclear genomic sequences from sediments by targeting, via hybridization capture, regions in the nuclear genome with high 
mammalian sequence diversity, and used these sequences to explore the history of Neanderthal populations in western Europe and southern Siberia.

\section{Archaeological sites}

We focused our analyses on sediments from three Paleolithic sites. Denisova Cave (4) and Chagyrskaya Cave (5), both located in the Altai Mountains (Fig. 1A), were included for their known mtDNA preservation in sediment (2), and to enable comparisons to three high-coverage nuclear genomes generated previously for bones from these sites: Denisova 5 [the Altai Neanderthal toe bone, dated to 90.9-130.0 thousand years (ka)] $(6,7)$, Denisova 3 (a Denisovan finger bone, 51.6$76.2 \mathrm{ka})(6,8)$ and Chagyrskaya 8 (a Neanderthal finger bone, $49.0-92 \mathrm{ka})(5,9)$. All age ranges include the $95 \%$ confidence interval (CI) of the dating method(s). Whereas Denisova Cave has evidence for at least 250 millennia of archaic human occupation (4), the Neanderthal-bearing deposits at Chagyrskaya Cave (Layers 5 and 6; Fig. $1 \mathrm{~B}$ and fig. S1) accumulated in less than 10 millennia (5).

The third site, Galería de las Estatuas ('Estatuas'), is part of the Atapuerca archaeo-paleontological complex in northern Spain (Fig. 1C and fig. S2). Almost 500 stone artifacts with clear Mousterian affinities, combined with single-grain optical dating of the associated sediments, indicate Neanderthal occupation from at least $113 \pm 8$ to $70 \pm 5 \mathrm{ka}$ ago [total uncertainty at $1 \sigma ;(10,11)]$, yet only a single Neanderthal foot phalanx has been recovered (12) (Fig. S3). Initial screening of the Estatuas sediments indicated the presence of ancient mammalian mtDNA, including that of hominins [figs. S4 to S6 and tables S10 and S11 (13)]. Analysis of sediment DNA may therefore be the only viable approach for reconstructing the population genetics of the occupants of this site during a time period not currently well represented in the genetic record of European Neanderthals.

For Denisova Cave, we retrieved nuclear DNA from three existing sediment samples with hominin mtDNA preservation, from Layers 11.4 and 15 in East Chamber and Layer 14.3 in Main Chamber $(2,4)$. At Chagyrskaya Cave and Estatuas, we extensively sampled across the Paleolithic layers, collecting 76 samples from two pits at Estatuas and 73 samples from Chagyrskaya Cave [Fig. 1, B and C, and figs. S4 and S5 (13)], and targeted both mitochondrial and nuclear hominin DNA.

\section{Retrieval of hominin mtDNA}

We enriched hominin mtDNA from Chagyrskaya Cave and Estatuas samples using protocols for automated DNA extraction (14), library preparation (15) and hybridization capture (2). To maximize the number of libraries containing sufficient amounts of hominin DNA for analysis, multiple subsamples were taken from some of the Estatuas samples, and several libraries produced from some subsamples, for a total of 369 libraries. After assigning sequences to mammalian families using MEGAN (16) we found that $74 \%$ of samples $(n=54)$ from Chagyrskaya and $56 \%(n=43)$ from Estatuas yielded at least one library containing hominin mtDNA fragments with significantly elevated frequencies of cytosine (C) to thymine (T) substitutions at their $5^{\prime}$ and $3^{\prime}$ ends, compatible with the presence of deaminated ancient DNA [table S10 (13)]. Of the 223 libraries containing ancient hominin mtDNA, 182 (82\%) yielded sufficient fragments to allow their assignment to a hominin group based on 'diagnostic' positions in the mtDNA genome that are derived in one hominin group (modern humans, Neanderthals, Denisovans or the Sima de los Huesos hominins) and ancestral in the others $(3,13)$. All such assignments were to Neanderthal mtDNA, consistent with archaeological evidence for the presence of Neanderthals in all layers - with exception of the upper portions of Layer 7 in Chagyrskaya Cave, which is archaeologically sterile and dated to $>300 \mathrm{ka}$. The detection of Neanderthal mtDNA near the top of Layer 7 may be due to it being a former living floor and/or a consequence of post-depositional mixing with sediments from the overlying Subunit 6c, resulting in Subunit 6d $(5,13)$.

Fourteen samples produced libraries with high coverage of the Neanderthal mtDNA genome (>17-fold) and point estimates of present-day human contamination lower than $10 \%$ (13). Four of these (from Chagyrskaya Subunit 6c, Estatuas pit II/Layer 2, and Estatuas pit I/Layers 3 and 4) appeared to contain a single mitochondrial sequence on the basis of the consistency of nucleotides observed at each position [fig. S7 and table S3 (13)]. These were used for generating near-complete consensus sequences and building a phylogenetic tree with BEAST2 (17), along with previously published hominin mtDNA sequences derived from skeletal remains or from present-day humans, and a sequence reconstructed from the Layer 14.3 sediment sample from Main Chamber in Denisova Cave (2) [Fig. 2A, fig. S8, and table S4 (13)].

Most strikingly, we find that the consensus mtDNA genome from Estatuas pit I/Layer 4 is most similar to the mtDNA of the 120 ka Neanderthal from Hohlenstein-Stadel (HST), Germany, which falls basal to all other known Neanderthal mitochondrial genomes $(18,19)$. The Estatuas pit I/Layer 4 sediments (dated to $112 \pm 7 \mathrm{ka}$ ) are broadly contemporaneous with $H S T$. The mtDNA genomes from Estatuas pit II/Layer $2(79 \pm 5 \mathrm{ka})$ and pit I/Layer $3(107 \pm 8 \mathrm{ka})$ group with mtDNA from the 60-70 ka Mezmaiskaya 1 individual from the northern Caucasus $(7,20)$, whereas the sequence for Chagyrskaya Subunit $6 \mathrm{c}$ groups with the mtDNA from Chagyrskaya 8 (9). We note that ages estimated from the branch lengths of the sediment mtDNA sequences in the tree, such as $136 \mathrm{ka}$ (95\% CI: 75-200 ka) for the Estatuas pit I/Layer 4 sample, match previously published ages for the respective sites and layers [table S5 (13)]. 
To further investigate mitochondrial diversity in the sediments from Chagyrskaya Cave and Estatuas, we developed a method to probabilistically place libraries with as few as 250 ancient fragments in the known Neanderthal mtDNA diversity [figs S9 to S12 (13)]. This method allowed phylogenetic assignments of mtDNA from 38 libraries from Chagyrskaya Cave and 59 from Estatuas, spanning most layers sampled in each cave (Fig. 2B). We find that Estatuas pit I/Layers 4 and 5 contain both $H S T$-like and non-HST-like Neanderthal mtDNA, often in the same subsample, with the latter largely grouping with Mezmaiskaya 1 and Scladina I-4a, a $\sim 130$ ka Neanderthal from western Europe $(19,21)$. HST-like mtDNA then disappears from the upper layers of Estatuas, leaving mtDNA predominantly related to the Mezmaiskaya 1-like consensus sequences from those layers (Fig. 2B). Simulated mixing of DNA from the upper layers and pit I/Layer 4 does not generate the observation of Mezmaiskaya 1 and Scladina I-4a-like DNA in pit I/Layer 4, indicating true heterogeneity of mtDNA in the lower layers, consistent with the previously observed integrity of the Estatuas stratigraphy $(11,13)$. In Chagyrskaya Cave, we find remarkable homogeneity: all samples from Layers 5 to 7 grouping with the Subunit $6 \mathrm{c}$ consensus sequence, Chagyrskaya 8 or Okladnikov 2 (also from the Altai region) $(22,23)$, with occasional support for Denisova 11-like sequences.

\section{Nuclear DNA enrichment method}

To extend the study of hominin DNA from sediments to the nuclear genome, we designed a probe-set targeting 1.6 million informative single nucleotide polymorphisms (SNPs) in the nuclear genome, and enriched for DNA fragments overlapping these sites via hybridization capture $(2,13)$. We employed several techniques to both reduce and measure the extent of mis-mapping of non-hominin faunal DNA, and evaluated these measures using simulated ancient brown bear (Ursus arctos) DNA, with fragment sizes and deamination profiles taken from an ancient DNA library (13). We found that faunal mis-alignment is drastically reduced in regions of high mammalian diversity (e.g., Fig. 3, A versus B), by at least 48 -fold where the human genome differs by 8 or more base pairs from at least one non-primate genome (in a 52 bp region centered on a target SNP; Fig. 3C). We therefore restricted our design to SNPs in these regions. We additionally assign each DNA fragment to the NCBI taxonomy using the metagenomics software Kraken (24), and restricted our analyses to fragments classified as primate (13). This metagenomic filtering step dramatically enriches for hominin DNA, reducing the alignment of simulated ancient bear DNA to the human reference genome by a factor of 140, versus 1.8fold for Neanderthal DNA (13). However, these approaches may not eliminate all faunal mis-alignment, particularly if the DNA originates from a species that is not well represented in the NCBI taxonomy. Therefore, we included in our probe design 98,887 'hominin diagnostic' sites, which are fixed-derived in hominins, chimpanzees and bonobos (Fig. $3 \mathrm{D})$. At these sites, ancestral alleles in the captured fragments are strongly indicative of the presence of non-hominin mammalian DNA [0.2\% ancestral in Neanderthal compared to 95.6\% in U. arctos DNA; Fig. 3E (13)], and can be used to estimate faunal mis-alignment proportions.

\section{Nuclear DNA recovery and sexing}

We first applied these methods to previously prepared libraries from three Denisova Cave sediments: two with Neanderthal and one with Denisovan mtDNA (2). All showed significant levels of C-to-T substitutions in DNA fragments overlapping our targeted SNPs, consistent with the presence of ancient nuclear DNA [fig. S14 and table S13 (13)]. One sample showed evidence of moderate ( 15\%) non-hominin faunal mis-alignment before metagenomic filtering, but filtering reduced this to $<1 \%$ (table S13). After filtering, 1764, 27,923 and 162,508 DNA fragments (459, 8698 and 42,103 with evidence of deamination) were retained from the three samples, representing up to $\sim 0.1 \mathrm{x}$ coverage of our targeted sites.

Having confirmed the presence of ancient hominin nuclear DNA, we next asked whether we could assign each sample to a hominin group. By examining deaminated DNA fragments at sites where the high-coverage Denisovan and Altai Neanderthal genomes are homozygous and differ from each other, we find that in the two samples containing Neanderthal mtDNA, approximately $90 \%$ of DNA fragments carry the Neanderthal derived state, versus $2 \%$ carrying the Denisovan derived state (Fig. 4A, top left, red points). In contrast, the nuclear DNA in the sample containing Denisovan mtDNA carries the Denisovan derived allele in $65 \%$ of cases, but no Neanderthal derived alleles (Fig. 4A, top left, blue point). These results are consistent with those obtained from lowcoverage Neanderthal and Denisovan genomes from skeletal remains [Fig. 4A, bottom right, red and blue points $(1,13,19$, 25-27)], suggesting that the nuclear DNA in the three sediment samples is either of Neanderthal or Denisovan origin, but not both.

We next captured nuclear DNA from Chagyrskaya Cave and Estatuas sediment samples: 29 samples yielded at least one library with significant evidence for deamination and $<5 \%$ faunal mis-alignment [tables S12 and S13 (13)]; four libraries showed evidence for $>5 \%$ faunal mis-alignment and were excluded from further analyses, highlighting the importance of per-library mis-alignment estimates [table S14 (13)]. In total, we retrieved nuclear DNA from Chagyrskaya Cave Subunits 6a-d and 7 [the latter likely intrusive from Subunits 6c and 6d (13)], and Estatuas pit II/Layer 2 and pit I/Layers 2-5. Recovery of hominin DNA was lower than for the Denisova Cave samples, with our best libraries yielding 
134,497 fragments (33,594 with evidence of deamination) at target sites for Chagyrskaya Cave and 47,667 for Estatuas (16,678 deaminated). In a plot of Neanderthal versus Denisovan alleles, these samples clearly contain Neanderthal nuclear DNA, and cluster together closely with Neanderthal skeletal samples (Fig. 4A, top right and bottom left). Equivalent plots considering sites that differ among the Altai Neanderthal, Vindija 33.19 or Chagyrskaya 8 genomes lack the resolution to resolve their relationship to these Neanderthal genomes, given the small amounts of data per sample at these SNPs [figs. S15 and S16 (13)].

For skeletal specimens, the relative proportions of $\mathrm{X}$ and autosomal DNA have been used to determine sex (3). We applied this approach to sediment subsamples with $<10 \%$ present-day human contamination and deaminated DNA fragments covering at least 5,000 sites, and find that all such Denisova Cave and Estatuas samples show X/autosome proportions consistent with hominin DNA originating primarily from a single sex (three male and three female; Fig. 4B and fig. S17). In contrast, the majority of samples from Chagyrskaya Cave fall between the expected male and female proportions, suggesting that they contain DNA from multiple individuals of different sexes (Fig. 4B). All four libraries for which we identified a single mtDNA sequence have $\mathrm{X} /$ autosome proportions consistent with the DNA originating from a single sex, suggesting that they may contain DNA from individual Neanderthals (Fig. 4B, black-labeled sediment points), although we cannot exclude the presence of identical mtDNA from multiple individuals of the same sex.

\section{Nuclear phylogenetic analysis}

To place each sample on the larger archaic phylogeny despite limited data, we developed a maximum likelihood framework which, for a sample $X$, co-estimates the point at which $X$ branched from the archaic hominin tree - defined by the three Neanderthal and one Denisovan high-coverage genomes (e.g., Neanderthal phylogeny in Fig. 4C) - along with the proportion of fragments deriving from non-hominin faunal mis-alignment and present-day human contamination. This method makes use of the fact that all sites which are polymorphic in archaic hominins are informative for their population histories. For example, at a site which is heterozygous in one archaic genome but homozygous ancestral in the others, the probability of observing a derived allele in a sample $X[\mathrm{p}(X=$ der $)]$ varies based on the point at which $X$ diverged from the overall tree (Fig. $4 \mathrm{C}$, black points and bar plot). These probabilities are obtained from coalescent simulations for which effective population sizes and split times are inferred from the respective high-coverage genomes (13). Mis-alignment and contamination proportions are estimated independently for deaminated and non-deaminated fragments, allowing all fragments to be used in the analysis (13).
Although some sediment samples may represent single individuals, this method operates on allele frequency expectations, making it equally applicable to samples representing single or multiple individuals from a population. When applied to previously published low-coverage genomes from skeletal samples, our method infers population split times and contamination proportions consistent with previous estimates (13). In a power analysis, we estimate accurate population split times in down-sampled low-coverage Neanderthal genomes (25) with up to $70 \%$ present-day human contamination [mean absolute error 10-16 ka with 500 Neanderthal DNA fragments; 4-7 ka with 4000 fragments; figs. S18 to S22 (13)], and accurately infer present-day human contamination proportions of up to $90 \%$ [fig. S20 (13)].

Applying this method to sediment libraries from Denisova and Chagyrskaya Caves, we find results consistent with previously published ancient DNA from skeletal elements. Specifically, we find that the two Neanderthal samples from Denisova Cave fall on the lineage leading to the Altai Neanderthal individual (Fig. 4D, De-E11.4 and De-M14.3, and table S14). This result is consistent with the first of these samples originating from the same layer in East Chamber (Layer 11.4) as the Altai Neanderthal, and the second sample from a contemporaneous layer (Layer 14.3) in Main Chamber (deposited approximately 105-120 and 97-112 ka ago, respectively) (4). The Denisovan sample from Layer 15 in East Chamber (dated to $\sim 200 \mathrm{ka}$ ) (4) falls on the Denisovan lineage, consistent with its mtDNA [fig. S23 (2)]. The sediment samples from all layers at Chagyrskaya Cave fall on the Chagyrskaya 8 lineage (Fig. 4D, Ch-3058a and Ch-3007a, and fig. S24), consistent with a short-lived occupation of the site by Neanderthals associated with a distinctive Middle Paleolithic toolkit (5).

For Estatuas, where less nuclear DNA was recovered from the sediment samples and no previous genetic data exist from skeletal remains, we estimated population split times for individual subsamples with at least 500 Neanderthal DNA fragments and less than $70 \%$ present-day human contamination. We also merged samples to obtain per-layer estimates, with 5000-36,000 fragments per layer (Fig. 5A). Samples from pit II/Layer 2, pit I/Layer 2 and pit I/Layer 3 (10) diverge from the Neanderthal tree approximately 100-115 ka (block bootstrap 95\% CIs: 102-114, 99-122 and 102-112 ka, respectively; Fig. 5A), similar to the split times of Vindija 33.19, Chagyrskaya 8 and Mezmaiskaya 1 from each other ( 104 ka; Fig. 5, B and C). The time of deposition of pit I/Layer 3 [107 $\pm 8 \mathrm{ka} ;(10,13)]$ is indistinguishable from this date of divergence, suggesting that the Neanderthals from pit I/Layer 3 were closely related to the ancestors of Vindija 33.19 and Chagyrskaya 8 . We are unable to determine whether the aforementioned layers represent a repeated occupation of the cave by the same Neanderthal population, but the split times and the mtDNA data (Fig. 2B) are consistent with this hypothesis. 
In contrast, sediments from pit $\mathrm{I} /$ Layer 4 carrying the HST-like mtDNA diverge from the Neanderthal tree approximately 122-135 ka ago (Fig. 5A, block bootstrap 95\% CI). This divergence time is similar to that of the HST Neanderthal itself, as well as of the Scladina and Altai Neanderthals (Fig. 5, $\mathrm{B}$ and $\mathrm{C})$. The latter two carry the more common non-HSTlike Neanderthal mtDNA type (Fig. 5B), consistent with mitochondrial diversity in the ancestral Neanderthal population, which is also observed in pit I/Layer 4 (Fig. 2B). GE-IB33f, the only sample of the common Neanderthal mtDNA type from pit I/Layer 4 that yielded nuclear DNA, was collected from near the boundary with Layer 3 and produced a divergence time similar to those of the Layer 3 samples, albeit with a large CI (83-139 ka) due to the small data set (867 ancient hominin DNA fragments). Taken together, these observations suggest that a population replacement occurred at Estatuas toward the end of the time of deposition of Layer 4, which was accompanied by a loss of mtDNA diversity. Similar results were obtained when using only deaminated fragments (fig. S25), highlighting the robustness of the method to the effects of present-day human contamination.

\section{Discussion}

The apparent clustering of branching times suggests two distinct radiations of Neanderthal populations: Mezmaiskaya 1, Vindija 33.19, Chagyrskaya 8 and Estatuas pit II/Layer 2 and pit I/Layers 2 and 3 diverged from each other approximately 100-115 ka, whereas the Altai, HST, Scladina and Estatuas pit I/Layer 4 Neanderthals, and the lineage leading to Vindija 33.19 and Chagyrskaya 8, diverged from each other $\sim 135 \mathrm{ka}$ ago (Fig. 5C). These radiation events therefore occurred during the early part of the Late Pleistocene and may be associated with changes in climate and environmental conditions during the last interglacial. In addition, it has been noted that the typical Neanderthal morphology evolved in several stages $(28,29)$, with the last stage, the "classic" Neanderthals, appearing around 100,000 years ago. Despite the uncertainty in dating these events, it seems plausible that the latter transition could be linked to the younger population radiation we detected. However, to detect if such factors played a key role in the population dynamics of Neanderthals and other Pleistocene hominins $(30,31)$ would require time-series data from additional sites and more precise estimates of the timing of these genetic events of interest. The methods presented here open the possibility to obtain such data independently of the fossil record, limited only by biochemical constraints on longterm DNA preservation.

Our results also show that the recovery of hominin DNA from sediment may not be limited to population samples, as DNA that putatively derived from individual Neanderthals (i.e., sediment samples with a single mtDNA sequence and sex) was identified in sediment samples from all three study sites. This observation suggests that it may be possible, in the future, to also assess heterogeneity in the genetic composition of past populations based on the analysis of sediment DNA. In light of the substantial variation in the quantity of hominin DNA observed among sediment samples taken in close proximity (and within single samples), and considering the low abundance of hominin DNA compared to non-hominin faunal DNA, it seems unlikely that the analysis of hominin DNA from Pleistocene sediments is significantly impacted-if at all-by leaching of DNA through archaeological layers. However, the presence of Neanderthal DNA in Layer 7 of Chagyrskaya Cave highlights the need to evaluate evidence for post-depositional mixing of sediments when assigning DNA sequences from sediment to specific layers, as is common practice when interpreting finds of artifacts, skeletal remains and other archaeological materials. Finally, our work also highlights the value of high-coverage archaic human genomes, even if generated only in small numbers, as scaffolding for defining the past genetic landscape on to which less complete genome-wide sequence data from sediments and bones can be mapped.

\section{Materials and methods}

Sediment samples were taken from the exposed sections of Chagyrskaya Cave and Galería de las Estatuas, and sub-samples with a weight between 21 and $128 \mathrm{mg}$ used for DNA extraction (14) and single-stranded DNA library preparation (15). All libraries were enriched for hominin mtDNA using hybridization capture (32), and a sub-set for mammalian mtDNA (33) to evaluate the preservation of ancient faunal DNA. Based on the content of ancient hominin mtDNA, and aiming to recover hominin nuclear DNA from all relevant layers, libraries from this study and a previous study on DNA preservation in the sediments of Denisova Cave (2) were selected for hybridization capture using probes targeting phylogenetically informative positions in the nuclear genome. Mitochondrial sequences were identified on the biological family level using a previously established analysis pipeline (2), which includes an evaluation of the presence of deamination patterns typical for ancient DNA and assignments of the Hominidae component to specific hominid groups. Further assignments to specific branches of the hominin mtDNA tree were performed using a method based on the software kallisto $(13,34)$. Hominin nuclear DNA sequences were identified and phylogenetic analyses performed as summarized in fig. S26 and described in full detail in (13), together with details on sample collection, sample preparation, data processing and the computational and phylogenetic analyses performed (13). Software and scripts written were in Python (35) and $\mathrm{R}(36)$, and plots were created with ggplot2 (37), cowplot (38), RColorBrewer (39) and ggmap (40), and are publicly available as described in (13). 


\section{REFERENCES AND NOTES}

1. V. Slon, F. Mafessoni, B. Vernot, C. de Filippo, S. Grote, B. Viola, M. Hajdinjak, S. Peyrégne, S. Nagel, S. Brown, K. Douka, T. Higham, M. B. Kozlikin, M. V. Shunkov, A. P. Derevianko, J. Kelso, M. Meyer, K. Prüfer, S. Pääbo, The genome of the offspring of a Neanderthal mother and a Denisovan father. Nature 561, 113-116 (2018). doi:10.1038/s41586-018-0455-x Medline

2. V. Slon, C. Hopfe, C. L. Weiß, F. Mafessoni, M. de la Rasilla, C. Lalueza-Fox, A. Rosas, M. Soressi, M. V. Knul, R. Miller, J. R. Stewart, A. P. Derevianko, Z. Jacobs, B. Li, R. G. Roberts, M. V. Shunkov, H. de Lumley, C. Perrenoud, I. Gušić, Ž. Kućan, P. Rudan, A. Aximu-Petri, E. Essel, S. Nagel, B. Nickel, A. Schmidt, K. Prüfer, J. Kelso, H. A. Burbano, S. Pääbo, M. Meyer, Neandertal and Denisovan DNA from Pleistocene sediments. Science 356, 605-608 (2017). doi:10.1126/science aam9695 Medline

3. M. Meyer, J.-L. Arsuaga, C. de Filippo, S. Nagel, A. Aximu-Petri, B. Nickel, I. Martínez, A. Gracia, J. M. Bermúdez de Castro, E. Carbonell, B. Viola, J. Kelso, K. Prüfer, S. Pääbo, Nuclear DNA sequences from the Middle Pleistocene Sima de los Huesos hominins. Nature 531, 504-507 (2016). doi:10.1038/nature17405 Medline

4. Z. Jacobs, B. Li, M. V. Shunkov, M. B. Kozlikin, N. S. Bolikhovskaya, A. K. Agadjanian, V. A. Uliyanov, S. K. Vasiliev, K. O'Gorman, A. P. Derevianko, R. G. Roberts, Timing of archaic hominin occupation of Denisova Cave in southern Siberia. Nature 565 , 594-599 (2019). doi:10.1038/s41586-018-0843-2 Medline

5. K. A. Kolobova, R. G. Roberts, V. P. Chabai, Z. Jacobs, M. T. Krajcarz, A. V. Shalagina, A. I. Krivoshapkin, B. Li, T. Uthmeier, S. V. Markin, M. W. Morley, K. O'Gorman, N. A. Rudaya, S. Talamo, B. Viola, A. P. Derevianko, Archaeological evidence for two separate dispersals of Neanderthals into southern Siberia. Proc. Natl. Acad. Sci. U.S.A. 117, 2879-2885 (2020). doi:10.1073/pnas. 1918047117 Medline

6. K. Douka, V. Slon, Z. Jacobs, C. B. Ramsey, M. V. Shunkov, A. P. Derevianko, F. Mafessoni, M. B. Kozlikin, B. Li, R. Grün, D. Comeskey, T. Devièse, S. Brown, B. Viola, L. Kinsley, M. Buckley, M. Meyer, R. G. Roberts, S. Pääbo, J. Kelso, T. Higham, Age estimates for hominin fossils and the onset of the Upper Palaeolithic at Denisova Cave. Nature 565, 640-644 (2019). doi:10.1038/s41586-018-0870$z$ Medline

7. K. Prüfer, F. Racimo, N. Patterson, F. Jay, S. Sankararaman, S. Sawyer, A. Heinze, G. Renaud, P. H. Sudmant, C. de Filippo, H. Li, S. Mallick, M. Dannemann, Q. Fu, M. Kircher, M. Kuhlwilm, M. Lachmann, M. Meyer, M. Ongyerth, M. Siebauer, C. Theunert, A. Tandon, P. Moorjani, J. Pickrell, J. C. Mullikin, S. H. Vohr, R. E. Green, I. Hellmann, P. L. F. Johnson, H. Blanche, H. Cann, J. O. Kitzman, J. Shendure, E. E. Eichler, E. S. Lein, T. E. Bakken, L. V. Golovanova, V. B. Doronichev, M. V. Shunkov, A. P. Derevianko, B. Viola, M. Slatkin, D. Reich, J. Kelso, S. Pääbo, The complete genome sequence of a Neanderthal from the Altai Mountains. Nature 505, 43-49 (2014). do: 10.1038/nature12886 Medline

8. M. Meyer, M. Kircher, M.-T. Gansauge, H. Li, F. Racimo, S. Mallick, J. G. Schraiber, F. Jay, K. Prüfer, C. de Filippo, P. H. Sudmant, C. Alkan, Q. Fu, R. Do, N. Rohland, A. Tandon, M. Siebauer, R. E. Green, K. Bryc, A. W. Briggs, U. Stenzel, J. Dabney, J. Shendure, J. Kitzman, M. F. Hammer, M. V. Shunkov, A. P. Derevianko, N. Patterson, A. M. Andrés, E. E. Eichler, M. Slatkin, D. Reich, J. Kelso, S. Pääbo, A high-coverage genome sequence from an archaic Denisovan individual. Science 338, 222-226 (2012). doi:10.1126/science.1224344 Medline

9. F. Mafessoni, S. Grote, C. de Filippo, V. Slon, K. A. Kolobova, B. Viola, S. V. Markin, M. Chintalapati, S. Peyrégne, L. Skov, P. Skoglund, A. I. Krivoshapkin, A. P. Derevianko, M. Meyer, J. Kelso, B. Peter, K. Prüfer, S. Pääbo, A high-coverage Neandertal genome from Chagyrskaya Cave. Proc. Natl. Acad. Sci. U.S.A. 117, 15132-15136 (2020). doi:10.1073/pnas.2004944117Medline

10. M. Demuro, L. J. Arnold, A. Aranburu, A. Gómez-Olivencia, J.-L. Arsuaga, Singlegrain OSL dating of the Middle Palaeolithic site of Galería de las Estatuas, Atapuerca (Burgos, Spain). Quat. Geochronol. 49, 254-261 (2019). doi:10.1016/i.quageo.2018.02.006

11. J. L. Arsuaga, A. Gómez-Olivencia, N. Sala, V. Martínez-Pillado, A. Pablos, A. Bonmatí, A. Pantoja-Pérez, J. Lira-Garrido, A. Alcázar de Velasco, A. I. Ortega, G. Cuenca-Bescós, N. García, A. Aranburu, B. Ruiz-Zapata, M. José Gil-García, X. P. Rodríguez-Álvarez, A. Ollé, M. Mosquera, Evidence of paleoecological changes and Mousterian occupations at the Galería de las Estatuas site, Sierra de Atapuerca, northern Iberian plateau, Spain. Quat. Res. 88, 345-367 (2017). doi:10.1017/qua.2017.46
12. A. Pablos, A. Gómez-Olivencia, J. L. Arsuaga, A Neandertal foot phalanx from the Galería de las Estatuas site (Sierra de Atapuerca, Spain). Am. J. Phys. Anthropol. 168, 222-228 (2019). doi:10.1002/aipa.23729 Medline

13. Materials and methods are available as supplementary materials.

14. N. Rohland, I. Glocke, A. Aximu-Petri, M. Meyer, Extraction of highly degraded DNA from ancient bones, teeth and sediments for high-throughput sequencing. Nat. Protoc. 13, 2447-2461 (2018). do:10.1038/s41596-018-0050-5 Medline

15. M.-T. Gansauge, A. Aximu-Petri, S. Nagel, M. Meyer, Manual and automated preparation of single-stranded DNA libraries for the sequencing of DNA from ancient biological remains and other sources of highly degraded DNA. Nat. Protoc. 15, 2279-2300 (2020). doi:10.1038/s41596-020-0338-0 Medline

16. D. H. Huson, S. Beier, I. Flade, A. Górska, M. El-Hadidi, S. Mitra, H.-J. Ruscheweyh, R. Tappu, MEGAN Community Edition - Interactive Exploration and Analysis of Large-Scale Microbiome Sequencing Data. PLOS Comput. Biol. 12, e1004957 (2016). doi:10.1371/journal.pcbi.1004957 Medline

17. R. Bouckaert, J. Heled, D. Kühnert, T. Vaughan, C.-H. Wu, D. Xie, M. A. Suchard, A. Rambaut, A. J. Drummond, BEAST 2: A software platform for Bayesian evolutionary analysis. PLOS Comput. Biol. 10, e1003537 (2014). doi:10.1371/journal.pcbi.1003537Medline

18. C. Posth, C. Wißing, K. Kitagawa, L. Pagani, L. van Holstein, F. Racimo, K Wehrberger, N. J. Conard, C. J. Kind, H. Bocherens, J. Krause, Deeply divergent archaic mitochondrial genome provides lower time boundary for African gene flow into Neanderthals. Nat. Commun. 8, 16046 (2017). doi:10.1038/ncomms16046 Medline

19. S. Peyrégne, V. Slon, F. Mafessoni, C. de Filippo, M. Hajdinjak, S. Nagel, B. Nickel, E. Essel, A. Le Cabec, K. Wehrberger, N. J. Conard, C. J. Kind, C. Posth, J. Krause, G. Abrams, D. Bonjean, K. Di Modica, M. Toussaint, J. Kelso, M. Meyer, S. Pääbo, K. Prüfer, Nuclear DNA from two early Neandertals reveals 80,000 years of genetic continuity in Europe. Sci. Adv. 5, eaaw5873 (2019). doi:10.1126/sciadv.aaw5873 Medline

20. A. R. Skinner, B. A. B. Blackwell, S. Martin, A. Ortega, J. I. B. Blickstein, L. V. Golovanova, V. B. Doronichev, ESR dating at Mezmaiskaya Cave, Russia. Appl. Radiat. Isot. 62, 219-224 (2005). doi:10.1016/i.apradiso.2004.08.008 Medline

21. M. Toussaint, D. Bonjean, The Scladina I-4A Juvenile Neandertal, Andenne, Belgium: Palaeoanthropology and Context (Université de Liège, 2014).

22. P. Skoglund, B. H. Northoff, M. V. Shunkov, A. P. Derevianko, S. Pääbo, J. Krause, M. Jakobsson, Separating endogenous ancient DNA from modern day contamination in a Siberian Neandertal. Proc. Natl. Acad. Sci. U.S.A. 111, 22292234 (2014). doi:10.1073/pnas.1318934111 Medline

23. K. A. Kolobova, A. V. Shalagina, V. P. Chabai, S. V. Markin, A. I. Krivoshapkin, Signification des technologies bifaciales au Paléolithique moyen des montagnes de l'Altaï. Anthropologie 123, 276-288 (2019). doi:10.1016/i.anthro.2019.06.004

24. D. E. Wood, S. L. Salzberg, Kraken: Ultrafast metagenomic sequence classification using exact alignments. Genome Biol. 15, R46 (2014). doi:10.1186/gb-2014-15-3r46 Medline

25. M. Hajdinjak, Q. Fu, A. Hübner, M. Petr, F. Mafessoni, S. Grote, P. Skoglund, V. Narasimham, H. Rougier, I. Crevecoeur, P. Semal, M. Soressi, S. Talamo, J.-J. Hublin, I. Gušić, Ž. Kućan, P. Rudan, L. V. Golovanova, V. B. Doronichev, C. Posth, J. Krause, P. Korlević, S. Nagel, B. Nickel, M. Slatkin, N. Patterson, D. Reich, K. Prüfer, M. Meyer, S. Pääbo, J. Kelso, Reconstructing the genetic history of late Neanderthals. Nature 555, 652-656 (2018). doi:10.1038/nature26151 Medline

26. K. Prüfer, C. de Filippo, S. Grote, F. Mafessoni, P. Korlević, M. Hajdinjak, B. Vernot, L. Skov, P. Hsieh, S. Peyrégne, D. Reher, C. Hopfe, S. Nagel, T. Maricic, Q. Fu, C. Theunert, R. Rogers, P. Skoglund, M. Chintalapati, M. Dannemann, B. J. Nelson, F. M. Key, P. Rudan, Ž. Kućan, I. Gušić, L. V. Golovanova, V. B. Doronichev, N. Patterson, D. Reich, E. E. Eichler, M. Slatkin, M. H. Schierup, A. M. Andrés, J. Kelso, M. Meyer, S. Pääbo, A high-coverage Neandertal genome from Vindija Cave in Croatia. Science 358, 655-658 (2017). doi:10.1126/science.aao1887 Medline

27. S. Sawyer, G. Renaud, B. Viola, J.-J. Hublin, M.-T. Gansauge, M. V. Shunkov, A. P. Derevianko, K. Prüfer, J. Kelso, S. Pääbo, Nuclear and mitochondrial DNA sequences from two Denisovan individuals. Proc. Natl. Acad. Sci. U.S.A. 112, 15696-15700 (2015). doi:10.1073/pnas.1519905112 Medline

28. D. Dean, J.-J. Hublin, R. Holloway, R. Ziegler, On the phylogenetic position of the pre-Neandertal specimen from Reilingen, Germany. J. Hum. Evol. 34, 485-508 (1998). doi:10.1006/ihev.1998.0214 Medline 
29. J. L. Arsuaga, I. Martínez, L. J. Arnold, A. Aranburu, A. Gracia-Téllez, W. D. Sharp, R. M. Quam, C. Falguères, A. Pantoja-Pérez, J. Bischoff, E. Poza-Rey, J. M. Parés, J. M. Carretero, M. Demuro, C. Lorenzo, N. Sala, M. Martinón-Torres, N. García, A. Alcázar de Velasco, G. Cuenca-Bescós, A. Gómez-Olivencia, D. Moreno, A. Pablos, C.-C. Shen, L. Rodríguez, A. I. Ortega, R. García, A. Bonmatí, J. M. Bermúdez de Castro, E. Carbonell, Neandertal roots: Cranial and chronological evidence from Sima de los Huesos. Science 344, 1358-1363 (2014). doi:10.1126/science. 1253958 Medline

30. R. Potts, Evolution and environmental change in early human prehistory. Annu. Rev. Anthropol. 41, 151-167 (2012). doi:10.1146/annurev-anthro-092611-145754

31. J.-J. Hublin, "Climatic changes, paleogeography, and the evolution of the Neandertals," in Neandertals and Modern Humans in Western Asia, T. Akazawa, K. Aoki, O. Bar-Yosef, Eds. (Springer, 1998), pp. 295-310.

32. Q. Fu, M. Meyer, X. Gao, U. Stenzel, H. A. Burbano, J. Kelso, S. Pääbo, DNA analysis of an early modern human from Tianyuan Cave, China. Proc. Natl. Acad. Sci. U.S.A. 110, 2223-2227 (2013). doi:10.1073/pnas.1221359110 Medline

33. V. Slon, I. Glocke, R. Barkai, A. Gopher, I. Hershkovitz, M. Meyer, Mammalian mitochondrial capture, a tool for rapid screening of DNA preservation in faunal and undiagnostic remains, and its application to Middle Pleistocene specimens from Qesem Cave (Israel). Quat. Int. 398, 210-218 (2016). doi:10.1016/i.quaint.2015.03.039

34. N. L. Bray, H. Pimentel, P. Melsted, L. Pachter, Near-optimal probabilistic RNA-seq quantification. Nat. Biotechnol. 34, 525-527 (2016). doi:10.1038/nbt3519 Medline

35. G. Van Rossum, F. L. Drake Jr., "Python tutorial" (Centrum voor Wiskunde en Informatica, 1995).

36. R Core Team, "R: A language and environment for statistical computing" ( $R$ Foundation for Statistical Computing, 2019); https://www.R-project.org/.

37. H. Wickham, "ggplot2: Elegant graphics for data analysis" (Tidyverse, 2016); https://ggplot2.tidyverse.org.

38. C. O. Wilke, "cowplot: Streamlined plot theme and plot annotations for "ggplot2" (R package version 1.1.1, 2019); https://CRAN.R-project.org/package=cowplot

39. E. Neuwirth, "RColorBrewer: ColorBrewer palettes" ( R package 1.1-2, 2014); https://CRAN.R-project.org/package=RColorBrewer.

40. D. Kahle, H. Wickham, ggmap: Spatial Visualization with ggplot2. R J. 5, 144-161 (2013). doi:10.32614/RJ-2013-014

41. B. Vernot, "bvernot/branch_estim: v0.1-beta" (Zenodo, 2021); https://zenodoorg/record/4534664.

42. B. Vernot, "bvernot/make_sed_capture_targets: v0.1-beta" (Zenodo, 2021); https://zenodo.org/record/4534734.

43. F. Romagne, "mpieva/nuclear_sediment_pipeline: metagen_utils v1.21" (Zenodo, 2021); https://zenodo.org/record/4468181.

44. J. Visagie, "mpieva/biohazard-tools: Biohazard Tools v0.2" (Zenodo, 2021); https://zenodo.org/record/4616582.

45. K. Prüfer, "Alignments of modern and archaic human genomes with primate outgroup genomes in tab-separated-values format" (EDMOND, 2021); https://dx.doi.org/10.17617/3.5h.

46. J.-L. Arsuaga, I. Martínez, A. Gracia, J.-M. Carretero, E. Carbonell, Three new human skulls from the Sima de los Huesos Middle Pleistocene site in Sierra de Atapuerca, Spain. Nature 362, 534-537 (1993). doi:10.1038/362534a0 Medline

47. J. M. Bermúdez de Castro, J. L. Arsuaga, E. Carbonell, A. Rosas, I. Martínez, M. Mosquera, A hominid from the lower Pleistocene of Atapuerca, Spain: Possible ancestor to Neandertals and modern humans. Science 276, 1392-1395 (1997). doi:10.1126/science. 276.5317.1392 Medline

48. J.-L. Arsuaga, I. Martínez, C. Lorenzo, A. Gracia, A. Muñoz, O. Alonso, J. Gallego, The human cranial remains from Gran Dolina Lower Pleistocene site (Sierra de Atapuerca, Spain). J. Hum. Evol. 37, 431-457 (1999). doi:10.1006/ihev.1999.0309 Medline

49. E. Carbonell, J. M. Bermúdez de Castro, J. M. Parés, A. Pérez-González, G. CuencaBescós, A. Ollé, M. Mosquera, R. Huguet, J. van der Made, A. Rosas, R. Sala, J. Vallverdú, N. García, D. E. Granger, M. Martinón-Torres, X. P. Rodríguez, G. M. Stock, J. M. Vergès, E. Allué, F. Burjachs, I. Cáceres, A. Canals, A. Benito, C. Díez, M. Lozano, A. Mateos, M. Navazo, J. Rodríguez, J. Rosell, J. L. Arsuaga, The first hominin of Europe. Nature 452, 465-469 (2008). do:10.1038/nature06815 Medline
50. J. L. Arsuaga, J.-M. Carretero, C. Lorenzo, A. Gómez-Olivencia, A. Pablos, L. Rodríguez, R. García-González, A. Bonmatí, R. M. Quam, A. Pantoja-Pérez, I. Martínez, A. Aranburu, A. Gracia-Téllez, E. Poza-Rey, N. Sala, N. García, A. Alcázar de Velasco, G. Cuenca-Bescós, J. M. Bermúdez de Castro, E. Carbonell, Postcranial morphology of the middle Pleistocene humans from Sima de los Huesos, Spain. Proc. Natl. Acad. Sci. U.S.A. 112, 11524-11529 (2015). doi:10.1073/pnas.1514828112 Medline

51. M. Mosquera, A. Olle, A. Pérez-González, X. P. Rodríguez, M. Vaquero, J. M. Verges, E. Carbonell, Valle de las Orquídeas: Un yacimiento al aire libre del Pleistoceno Superior en la Sierra de Atapuerca (Burgos). Trab. Prehist. 64, 143-155 (2007). doi:10.3989/tp.2007.v64.i2.113

52. M. Navazo, R. Alonso-Alcalde, A. Benito-Calvo, J. C. Díez, A. Pérez-González, E. Carbonell, Hundidero: Mis 4 open air neanderthal occupations in Sierra de Atapuerca. Archaeol. Ethnol. Anthropol. Eurasia 39, 29-41(2011). doi:10.1016/i.aeae.2012.02.004

53. L. J. Arnold, M. Demuro, M. Navazo, A. Benito-Calvo, A. Pérez-González, OSL dating of the Middle Palaeolithic Hotel California site, Sierra de Atapuerca, northcentral Spain. Boreas 42, 285-305 (2013). doi:10.1111/i.1502-3885.2012.00262x

54. M. Navazo, E. Carbonell, Neanderthal settlement patterns during MIS 4-3 in Sierra de Atapuerca (Burgos, Spain). Quat. Int. 331, 267-277 (2014). doi:10.1016/iquaint 2014.03.032

55. A. Aranburu, V. Martínez-Pillado, F. García, J. L. Arsuaga, A. Alcázar de Velasco, A. Bonmatí, N. García, A. Gracia, A. Gómez, J. Lira, C. Lorenzo, I. Martínez, A. I. Ortega, A. Pablos, A. Pantoja, R. M. Quam, N. Sala, in Avances de la Geomorfología en España 2010-2012. XII Reunión Nacional de Geomorfología, Santander, A. González-Díez, G. Fernández-Maroto, M. W. Doughty, J. Remondo, V. M. Bruschi, J. Bonachea, T. R. Díaz de Terán, Eds. (Sociedad Española de Geomorfología, 2012), pp. 397-400; https:/geomorfologia.es/publicaciones-socios/avancesde-la-geomorfolog\%C3\%ADa-en-espa\%C3\%B1a-2010-2012)

56. V. Martínez-Pillado, A. Aranburu, J. L. Arsuaga, B. Ruiz-Zapata, M. J. Gil-García, H. Stoll, I. Yusta, E. Iriarte, J. M. Carretero, R. L. Edwards, H. Cheng, Upper Pleistocene and Holocene palaeoenvironmental records in Cueva Mayor karst (Atapuerca, Spain) from different proxies: Speleothem crystal fabrics, palynology and archaeology. Int. J. Speleol. 43, 1-14 (2014). doi:10.5038/1827-806X.43.1.1

57. C. B. Ramsey, Probability and dating. Radiocarbon 40, 461-474 (1997) doi:10.1017/S0033822200018348

58. C. B. Ramsey, Bayesian analysis of radiocarbon dates. Radiocarbon 51, 337-360 (2009). doi:10.1017/S0033822200033865

59. P. J. Reimer, W. E. N. Austin, E. Bard, A. Bayliss, P. G. Blackwell, C. Bronk Ramsey, M. Butzin, H. Cheng, R. L. Edwards, M. Friedrich, P. M. Grootes, T. P. Guilderson, I. Hajdas, T. J. Heaton, A. G. Hogg, K. A. Hughen, B. Kromer, S. W. Manning, R. Muscheler, J. G. Palmer, C. Pearson, J. van der Plicht, R. W. Reimer, D. A. Richards, E. M. Scott, J. R. Southon, C. S. M. Turney, L. Wacker, F. Adolphi, U. Büntgen, M. Capano, S. M. Fahrni, A. Fogtmann-Schulz, R. Friedrich, P. Köhler, S. Kudsk, F. Miyake, J. Olsen, F. Reinig, M. Sakamoto, A. Sookdeo, S. Talamo, The IntCal20 Northern Hemisphere radiocarbon age calibration curve (0-55 cal kBP). Radiocarbon 62, 725-757 (2020). doi:10.1017/RDC.2020.41

60. H. Cheng, R. Lawrence Edwards, C.-C. Shen, V. J. Polyak, Y. Asmerom, J. Woodhead, J. Hellstrom, Y. Wang, X. Kong, C. Spötl, X. Wang, E. Calvin Alexander Jr., Improvements in ${ }^{230} \mathrm{Th}$ dating, ${ }^{230} \mathrm{Th}$ and ${ }^{234} \mathrm{U}$ half-life values, and U-Th isotopic measurements by multi-collector inductively coupled plasma mass spectrometry. Earth Planet. Sci. Lett. 371-372, 82-91(2013). doi:10.1016/j.eps.2013.04.006

61. A. H. Jaffey, K. F. Flynn, L. E. Glendenin, W. C. Bentley, A. M. Essling, Precision measurement of half-lives and specific activities of $235 \mathrm{U}$ and ${ }^{238} \mathrm{U}$. Phys. Rev. $\mathrm{C}$ Nucl. Phys. 4, 1889-1906 (1971). doi:10.1103/PhysRevC.4.1889

62. J. M. Parés, A. I. Ortega, A. Benito-Calvo, A. Aranburu, J. L. Arsuaga, J. M. Bermúdez de Castro, E. Carbonell, "Paleomagnetic constraints on the Atapuerca karst development (N Spain)," in Caves and Karst Across Time, J. M. Feinberg, Y. Gao, E. C. Alexander, Jr., Eds. (Geological Society of America, 2016), pp. 285-300.

63. A. W. Briggs, U. Stenzel, P. L. F. Johnson, R. E. Green, J. Kelso, K. Prüfer, M. Meyer, J. Krause, M. T. Ronan, M. Lachmann, S. Pääbo, Patterns of damage in genomic DNA sequences from a Neandertal. Proc. Natl. Acad. Sci. U.S.A. 104, 14616-14621 (2007). doi:10.1073/pnas.0704665104 Medline 
64. M. Meyer, A. W. Briggs, T. Maricic, B. Höber, B. Höffner, J. Krause, A. Weihmann, S. Pääbo, M. Hofreiter, From micrograms to picograms: Quantitative PCR reduces the material demands of high-throughput sequencing. Nucleic Acids Res. 36, e5 (2008). doi:10.1093/nar/gkm1095 Medline

65. M. Kircher, S. Sawyer, M. Meyer, Double indexing overcomes inaccuracies in multiplex sequencing on the Illumina platform. Nucleic Acids Res. 40, e3 (2012). doi:10.1093/nar/gkr771 Medline

66. G. Renaud, U. Stenzel, J. Kelso, leeHom: Adaptor trimming and merging for Illumina sequencing reads. Nucleic Acids Res. 42, e141 (2014). doi:10.1093/nar/gku699 Medline

67. H. Li, R. Durbin, Fast and accurate short read alignment with Burrows-Wheeler transform. Bioinformatics 25, 1754-1760 (2009) doi:10.1093/bioinformatics/btp324 Medline

68. K. D. Pruitt, G. R. Brown, S. M. Hiatt, F. Thibaud-Nissen, A. Astashyn, O. Ermolaeva, C. M. Farrell, J. Hart, M. J. Landrum, K. M. McGarvey, M. R. Murphy, N. A. O'Leary, S. Puiar, B. Rajput, S. H. Rangwala, L. D. Riddick, A. Shkeda, H. Sun, P. Tamez, R. E. Tully, C. Wallin, D. Webb, J. Weber, W. Wu, M. DiCuccio, P. Kitts, D. R. Maglott, T. D. Murphy, J. M. Ostell, RefSeq: An update on mammalian reference sequences. Nucleic Acids Res. 42 (D1), D756-D763 (2014). doi:10.1093/nar/gkt1114 Medline

69. S. F. Altschul, W. Gish, W. Miller, E. W. Myers, D. J. Lipman, Basic local alignment search tool. J. Mol. Biol. 215, 403-410 (1990). doi:10.1016/S00222836(05)80360-2 Medline

70. R. R. Hudson, Generating samples under a Wright-Fisher neutral model of genetic variation. Bioinformatics 18, 337-338 (2002). doi:10.1093/bioinformatics/182337Medline

71. T. Maricic, M. Whitten, S. Pääbo, Multiplexed DNA sequence capture of mitochondrial genomes using PCR products. PLOS ONE 5, e14004 (2010). doi:10.1371/journal.pone.0014004 Medline

72. R. M. Andrews, I. Kubacka, P. F. Chinnery, R. N. Lightowlers, D. M. Turnbull, N. Howell, Reanalysis and revision of the Cambridge reference sequence for human mitochondrial DNA. Nat. Genet. 23, 147 (1999). doi:10.1038/13779 Medline

73. R. E. Green, A.-S. Malaspinas, J. Krause, A. W. Briggs, P. L. F. Johnson, C. Uhler, M. Meyer, J. M. Good, T. Maricic, U. Stenzel, K. Prüfer, M. Siebauer, H. A. Burbano, M. Ronan, J. M. Rothberg, M. Egholm, P. Rudan, D. Brajković, Z. Kućan, I. Gusić, M. Wikström, L. Laakkonen, J. Kelso, M. Slatkin, S. Pääbo, A complete Neandertal mitochondrial genome sequence determined by high-throughput sequencing. Cell 134, 416-426 (2008). doi:10.1016/i.cell.2008.06.021 Medline

74. Q. Fu, A. Mittnik, P. L. F. Johnson, K. Bos, M. Lari, R. Bollongino, C. Sun, L. Giemsch, R. Schmitz, J. Burger, A. M. Ronchitelli, F. Martini, R. G. Cremonesi, J. Svoboda, P. Bauer, D. Caramelli, S. Castellano, D. Reich, S. Pääbo, J. Krause, A revised timescale for human evolution based on ancient mitochondrial genomes. Curr. Biol. 23, 553-559 (2013). doi:10.1016/i.cub.2013.02.044 Medline

75. S. Horai, K. Hayasaka, R. Kondo, K. Tsugane, N. Takahata, Recent African origin of modern humans revealed by complete sequences of hominoid mitochondrial DNAs. Proc. Natl. Acad. Sci. U.S.A. 92, 532-536 (1995). doi:10.1073/pnas.92.2532 Medline

76. K. Katoh, D. M. Standley, MAFFT multiple sequence alignment software version 7: Improvements in performance and usability. Mol. Biol. Evol. 30, 772-780 (2013). doi:10.1093/molbev/mst010 Medline

77. R. E. Kass, A. E. Raftery, Bayes factors. J. Am. Stat. Assoc. 90, 773-795 (1995) doi:10.1080/01621459.1995.10476572

78. G. Baele, W. L. S. Li, A. J. Drummond, M. A. Suchard, P. Lemey, Accurate model selection of relaxed molecular clocks in bayesian phylogenetics. Mol. Biol. Evol. 30, 239-243 (2013). doi:10.1093/molbev/mss243 Medline

79. A. D. Leaché, M. K. Fujita, V. N. Minin, R. R. Bouckaert, Species delimitation using genome-wide SNP data. Syst. Biol. 63, 534-542 (2014). doi:10.1093/sysbio/syu018 Medline

80. K. Tamura, M. Nei, Estimation of the number of nucleotide substitutions in the control region of mitochondrial DNA in humans and chimpanzees. Mol. Biol. Evol. 10, 512-526 (1993). Medline

81. R. E. Wood, T. F. G. Higham, T. De Torres, N. Tisnérat-Laborde, H. Valladas, J. E. Ortiz, C. Lalueza-Fox, S. Sánchez-Moral, J. C. Cañaveras, A. Rosas, D. Santamaría, M. De La Rasilla, A new date for the Neanderthals from El Sidrón Cave (Asturias, Northern Spain). Archaeometry 55, 148-158 (2013). doi:10.1111/i.14754754.2012.00671.x
82. L. Schaeffer, H. Pimentel, N. Bray, P. Melsted, L. Pachter, Pseudoalignment for metagenomic read assignment. Bioinformatics 33, 2082-2088 (2017). doi:10.1093/bioinformatics/btx106 Medline

83. P. Sagulenko, V. Puller, R. A. Neher, TreeTime: Maximum-likelihood phylodynamic analysis. Virus Evol. 4, vex042 (2018). doi:10.1093/ve/vex042 Medline

84. G. A. Taylor, H. Kirk, L. Coombe, S. D. Jackman, J. Chu, K. Tse, D. Cheng, E. Chuah, P. Pandoh, R. Carlsen, Y. Zhao, A. J. Mungall, R. Moore, I. Birol, M. Franke, M. A. Marra, C. Dutton, S. J. M. Jones, The Genome of the North American Brown Bear or Grizzly: Ursus arctos ssp. horribilis. Genes (Basel) 9, 598 (2018). doi:10.3390/genes 9120598 Medline

85. N. A. O'Leary, M. W. Wright, J. R. Brister, S. Ciufo, D. Haddad, R. McVeigh, B. Rajput, B. Robbertse, B. Smith-White, D. Ako-Adjei, A. Astashyn, A. Badretdin, Y. Bao, O. Blinkova, V. Brover, V. Chetvernin, J. Choi, E. Cox, O. Ermolaeva, C. M. Farrell, T. Goldfarb, T. Gupta, D. Haft, E. Hatcher, W. Hlavina, V. S. Joardar, V. K. Kodali, W. Li, D. Maglott, P. Masterson, K. M. McGarvey, M. R. Murphy, K. O'Neill, S. Pujar, S. H. Rangwala, D. Rausch, L. D. Riddick, C. Schoch, A. Shkeda, S. S. Storz, H. Sun, F. Thibaud-Nissen, I. Tolstoy, R. E. Tully, A. R. Vatsan, C. Wallin, D. Webb, W. Wu, M. J. Landrum, A. Kimchi, T. Tatusova, M. DiCuccio, P. Kitts, T. D. Murphy, K. D. Pruitt, Reference sequence (RefSeq) database at NCBI: Current status, taxonomic expansion, and functional annotation. Nucleic Acids Res. 44, D733D745 (2016). doi:10.1093/nar/gkv1189 Medline

86. K. Prüfer, snpAD: An ancient DNA genotype caller. Bioinformatics 34, 4165-4171 (2018). doi:10.1093/bioinformatics/bty507 Medline

87. J. Herrero, M. Muffato, K. Beal, S. Fitzgerald, L. Gordon, M. Pignatelli, A. J. Vilella, S. M. J. Searle, R. Amode, S. Brent, W. Spooner, E. Kulesha, A. Yates, P. Flicek, Ensembl comparative genomics resources. Database (Oxford) 2016, bav096 (2016). 10.1093/database/bav096 Medline

88. G. Benson, Tandem repeats finder: A program to analyze DNA sequences. Nucleic Acids Res. 27, 573-580 (1999). doi:101093/nar/272573 Medline

89. D. Karolchik, A. S. Hinrichs, T. S. Furey, K. M. Roskin, C. W. Sugnet, D. Haussler, W. J. Kent, The UCSC Table Browser data retrieval tool. Nucleic Acids Res. 32, D493D496 (2004). doi:10.1093/nar/gkh103 Medline

90. W. J. Kent, C. W. Sugnet, T. S. Furey, K. M. Roskin, T. H. Pringle, A. M. Zahler, D. Haussler, The human genome browser at UCSC. Genome Res. 12, 996-1006 (2002). doi:10.1101/gr 229102 Medline

91. Q. Fu, C. Posth, M. Hajdinjak, M. Petr, S. Mallick, D. Fernandes, A. Furtwängler, W. Haak, M. Meyer, A. Mittnik, B. Nickel, A. Peltzer, N. Rohland, V. Slon, S. Talamo, I. Lazaridis, M. Lipson, I. Mathieson, S. Schiffels, P. Skoglund, A. P. Derevianko, N. Drozdov, V. Slavinsky, A. Tsybankov, R. G. Cremonesi, F. Mallegni, B. Gély, E. Vacca, M. R. G. Morales, L. G. Straus, C. Neugebauer-Maresch, M. Teschler-Nicola, S. Constantin, O. T. Moldovan, S. Benazzi, M. Peresani, D. Coppola, M. Lari, S. Ricci, A. Ronchitelli, F. Valentin, C. Thevenet, K. Wehrberger, D. Grigorescu, H. Rougier, I. Crevecoeur, D. Flas, P. Semal, M. A. Mannino, C. Cupillard, H. Bocherens, N. J. Conard, K. Harvati, V. Moiseyev, D. G. Drucker, J. Svoboda, M. P. Richards, D. Caramelli, R. Pinhasi, J. Kelso, N. Patterson, J. Krause, S. Pääbo, D. Reich, The genetic history of Ice Age Europe. Nature 534, 200-205 (2016). doi:10.1038/nature17993 Medline

92. Q. Fu, M. Hajdinjak, O. T. Moldovan, S. Constantin, S. Mallick, P. Skoglund, N. Patterson, N. Rohland, I. Lazaridis, B. Nickel, B. Viola, K. Prüfer, M. Meyer, J. Kelso D. Reich, S. Pääbo, An early modern human from Romania with a recent Neanderthal ancestor. Nature 524, 216-219 (2015). doi:10.1038/nature14558 Medline

93. 1000 Genomes Project Consortium; G. R. Abecasis, A. Auton, L. D. Brooks, M. A. DePristo, R. M. Durbin, R. E. Handsaker, H. M. Kang, G. T. Marth, G. A. McVean, An integrated map of genetic variation from 1,092 human genomes. Nature 491, 5665 (2012). doi:10.1038/naturel1632 Medline

94. A. Smit, R. Hubley, P. Green, "RepeatMasker Open-4.0" (Institute for Systems Biology, 2013); http://www. repeatmasker.org

95. A. Morgulis, E. M. Gertz, A. A. Schäffer, R. Agarwala, A fast and symmetric DUST implementation to mask low-complexity DNA sequences. J. Comput. Biol. 13 1028-1040 (2006). doi:10.1089/cmb.2006.13.1028 Medline

96. C. de Filippo, M. Meyer, K. Prüfer, Quantifying and reducing spurious alignments for the analysis of ultra-short ancient DNA sequences. BMC Biol. 16, 121 (2018). doi:10.1186/s12915-018-0581-9 Medline 
97. T. Günther, C. Nettelblad, The presence and impact of reference bias on population genomic studies of prehistoric human populations. PLOS Genet. 15, e1008302 (2019). doi:10.1371/journal.pgen.1008302 Medline

98. C. L. Schoch, S. Ciufo, M. Domrachev, C. L. Hotton, S. Kannan, R. Khovanskaya, D. Leipe, R. Mcveigh, K. O'Neill, B. Robbertse, S. Sharma, V. Soussov, J. P. Sullivan, L. Sun, S. Turner, I. Karsch-Mizrachi, NCBI Taxonomy: A comprehensive update on curation, resources and tools. Database (Oxford) 2020, baaa062 (2020). doi:10.1093/database/baaa062 Medline

99. L. Bokelmann, M. Hajdinjak, S. Peyrégne, S. Brace, E. Essel, C. de Filippo, I. Glocke, S. Grote, F. Mafessoni, S. Nagel, J. Kelso, K. Prüfer, B. Vernot, I. Barnes, S. Pääbo, M. Meyer, C. Stringer, A genetic analysis of the Gibraltar Neanderthals. Proc. Natl. Acad. Sci. U.S.A. 116, 15610-15615 (2019). doi:10.1073/pnas.1903984116 Medline

100. H. Li, R. Durbin, Inference of human population history from individual wholegenome sequences. Nature 475, 493-496 (2011). doi:10.1038/nature10231 Medline

101. P. Skoglund, A. Götherström, M. Jakobsson, Estimation of population divergence times from non-overlapping genomic sequences: Examples from dogs and wolves. Mol. Biol. Evol. 28, 1505-1517 (2011). doi:10.1093/molbev/msq342 Medline

102. B. M. Peter, 100,000 years of gene flow between Neandertals and Denisovans in the Altai mountains. bioRxiv 990523 [Preprint]. 15 March 2020. https://doi.org/10.1101/2020.03.13.990523.

103. F. Racimo, G. Renaud, M. Slatkin, Joint estimation of contamination, error and demography for nuclear DNA from ancient humans. PLOS Genet. 12, e1005972 (2016). doi:10.1371/journal.pgen.1005972 Medline

\section{ACKNOWLEDGMENTS}

We thank S. Pääbo for supporting the project and commenting on the manuscript, Moritz C. Meyer and K. O'Gorman for help with sampling, B. Schellbach and A. Weihmann for help in the lab, S. Peyregne for data assistance, L. Jáuregui for organizational support, and the whole Galería de las Estatuas, Chagyrskaya Cave and Denisova Cave excavation and research teams for providing the foundations that made this project possible. Funding: This work was supported by the Max Planck Society, the European Research Council (Grant Agreement 694707 to Svante Pääbo) and the Australian Research Council (fellowships FL130100116 to R.G.R., FT140100384 to B.L. and FT150100138 to Z.J.). The archaeological field studies were funded by the Russian Foundation for Basic Research (project 20 29-010116 for M.B.K., M.V.S. and A.P.D.), the Russian Science Foundation (projects 21-18-00089 for M.B.K., M.V.S. and A.P.D. and 19-48-04107 to A.I.K.), and the Junta de Castilla y León and Fundación Atapuerca. The geological study in Chagyrskaya Cave was supported by the National Science Center, Poland (project 2018/29/B/ST10/00906 to M.T.K.). A.G.O. and N.S were supported by Ramón y Cajal (RYC-2017-22558) and Juan de la Cierva-Incorporación (IJCl2017-32804) fellowships, respectively. B.Vi.'s research was supported by an Insight grant of the Social Sciences and Humanities Research Council (Canada). Further support was provided by the FEDER/Ministerio de Ciencia e InnovaciónAgencia Estatal de Investigación (projects PGC2018-093925-B-C31, PGC2018093925-B-C32, and PGC2018-093925-B-C33). Author contributions: B.Ve. and M.M. conceived the study. A.G-O., Z.J., N.S., A.Pa., A.A., J.M.B., E.C., B.L., M.T.K., A.I.K., K.A.K., M.B.K., M.V.S., A.P.D., B.Vi., D.L.H., R.G.R., J-L.A., M.M. sampled sediments and/or provided archaeological context and interpretation of results. E.I.Z., E.E., S.N., B.N., J.R, A.S. performed aDNA extraction and sequencing. B.Ve., E.I.Z., V.S., F.M., F.R., A. Pe., M.P., S.G., B.P., J.K., M.M. analyzed data. B.Ve., E.I.Z., A.G-O., Z.J., V.S., R.G.R., J-L.A., M.M. wrote the manuscript with input from the remaining authors. Competing interests: The authors declare that they have no competing interests. Data and materials availability: All data needed to evaluate the conclusions in the paper are present in the paper and/or the supplementary materials. Sequencing data has been deposited in the ENA, reference number PRJEB42656. Software is archived at Zenodo (41-44). Primate alignments are available at https://dx.doi.org/10.17617/3.5h (45).

\section{SUPPLEMENTARY MATERIALS}

science. sciencemag.org/cgi/content/full/science.abf1667/DC1 Materials and Methods

Figs. S1 to S26

Tables S1 to S14

References (46-103)

MDAR Reproducibility Checklist

9 October 2020; accepted 31 March 2021

Published online 15 April 2021

10.1126/science.abf1667 

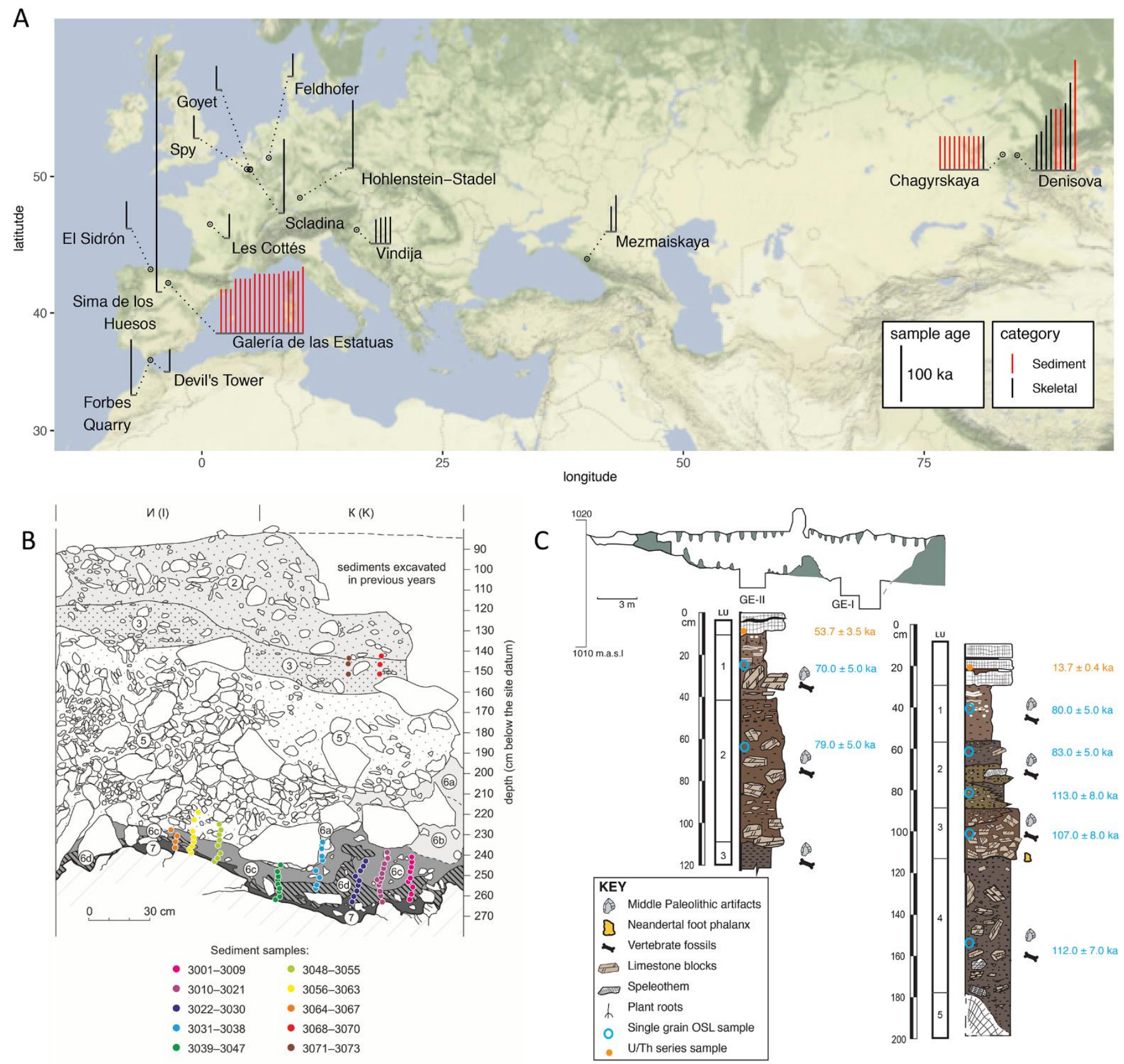

Fig. 1. Samples and stratigraphies. (A) Geographic locations of all skeletal (black) and sediment (red) samples with $>0.0001 x$ coverage. Each bar represents one sample; height is the age of the sample. (B) Stratigraphic profile of the sampled section at Chagyrskaya Cave. Sediment samples were collected in 10 vertical columns and numbered from bottom to top. Colored circles denote individual sample locations. (C) Cross-section of Galería de las Estatuas showing the locations of the two test pits, GE-I and GE-II, and detailed stratigraphic columns showing the lithostratigraphic units (LUs) and ages obtained. 


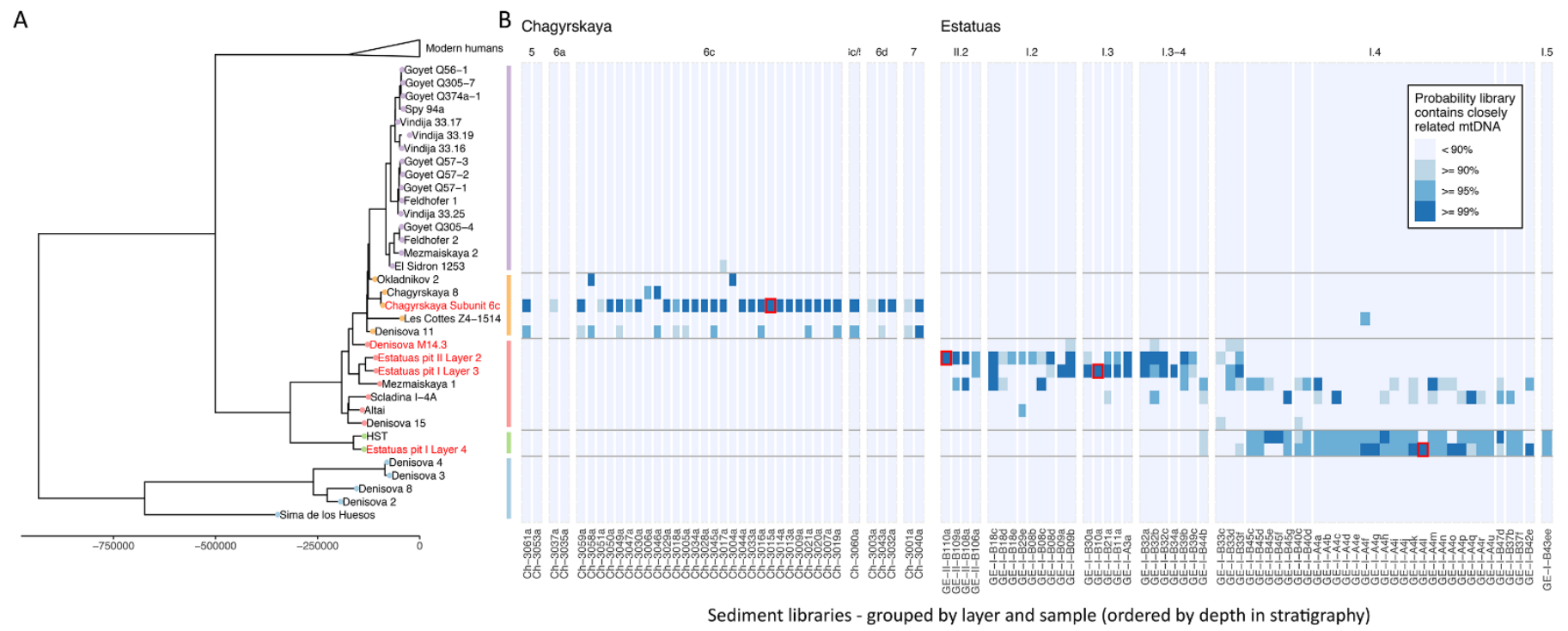

Fig. 2. Mitochondrial DNA from sediments. (A) Mitochondrial phylogeny, including five haplotypes inferred from sediment samples (red labels). Five mtDNA groupings are labeled (colored dots and vertical bars). (B) Probabilistic phylogenetic placement of mtDNA from 97 sediment sub-samples from 63 sediment samples, Chagyrskaya Cave (left) and Galería de las Estatuas (right). Samples divided by white lines. Sub-samples from which mtDNA haplotypes were inferred are denoted with red boxes. 
A

Low-diversity MSA - Chr1:19684006 (rev)

GTCTACCTCTGGGATCTGGATCATGGCTTTGCTGGAGTGATCCTCATAAAGA Homo sapiens

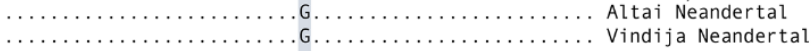

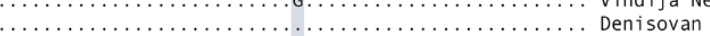

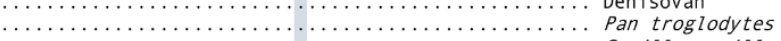

Gorilla gorilla

Pongo abeli $i$

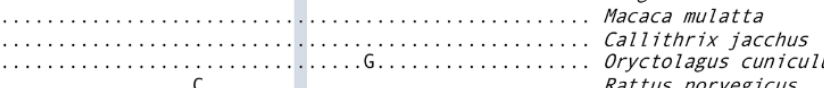

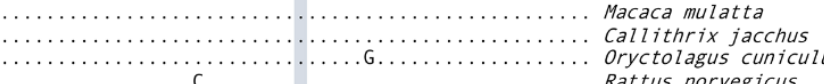

$\ldots \ldots \ldots \ldots \ldots \ldots \ldots \ldots \ldots \ldots \ldots \ldots \ldots \ldots \ldots \ldots \ldots \ldots \ldots \ldots \ldots \ldots \ldots \ldots$ Rattus norvegicus

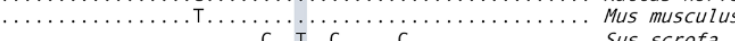

$\ldots \ldots \ldots \ldots \ldots \ldots \ldots$. Sus scrofa

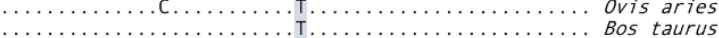

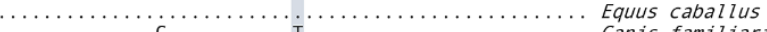

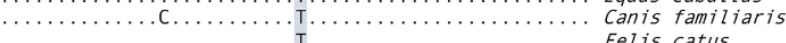

Fel is catus
B

High-diversity MSA - Chr1:11236464 (rev)

TGAGCGTTGCCCCAGCTGTGCCTGCAGATGCTCCTTG--CTGCCTGAGGACTTT Homo sapiens

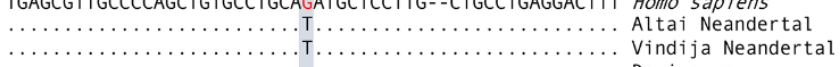

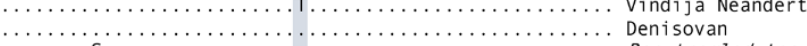

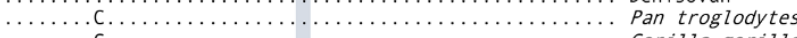

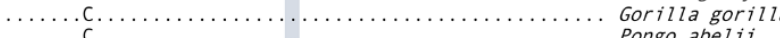

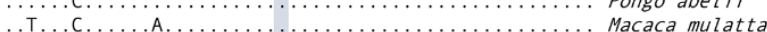

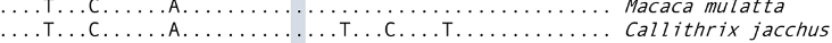

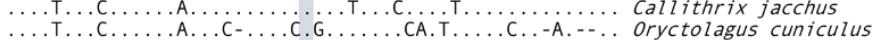

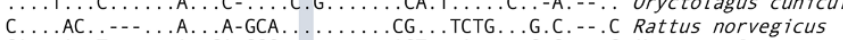

CA...A.T.-...A. .GA-GCC......................... Mus musculus

.A...AGCC.T. ............................... Sus scrofa

...TAG.C........CCA.............TT.G.....-G... Ovis aries

..TAG.C........CCA..............T.G..A...-G... Bos taurus

A...G-C............T........ -T.T......... Equus caballus

....G.C.............T............ . A........ Canis familiaris

.A...G.C.........A.C..........AT.T.A....... Fel is catus
C

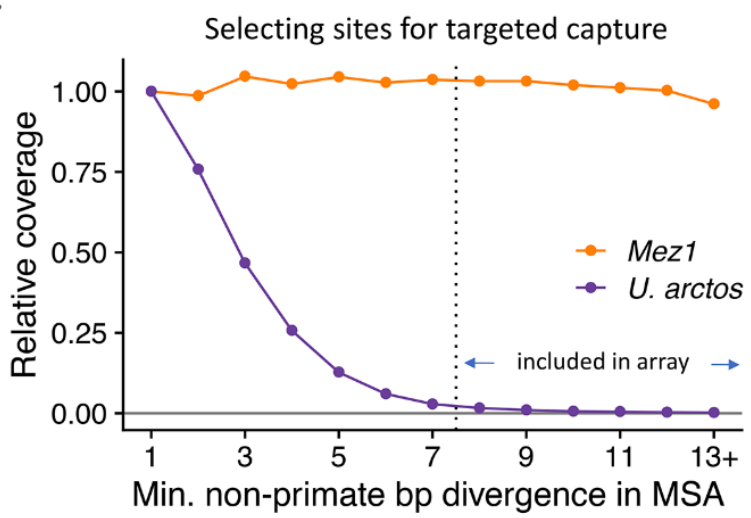

Hominin-diagnostic alleles

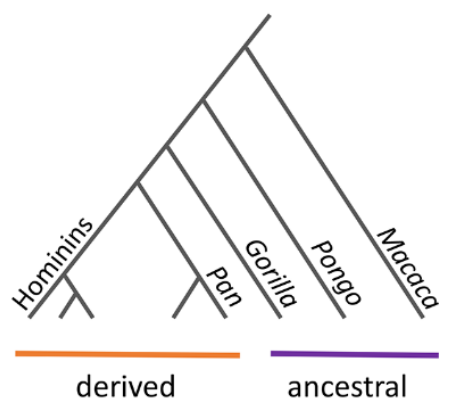

E

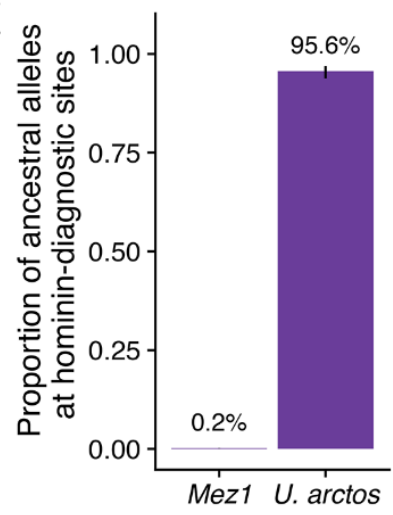

Fig. 3. Nuclear DNA capture design. (A) Multiple sequence alignment (MSA) of 15 mammalian species, two Neanderthals and one Denisovan. This region has low sequence diversity between hominins and non-primate mammals. (B) High-diversity MSA. (C) Faunal mis-alignment (purple) in the human genome as a function of mammalian diversity (the minimum base-pair divergence between Homo sapiens and nine non-primate mammalian sequences), - compared to the alignment of DNA fragments from the Mezmaiskaya 1 Neanderthal (orange; Mez1); $y$-axis is relative coverage compared to the first bin. (D) Ascertainment of hominin-diagnostic alleles; ancestral alleles are indicative of faunal-misalignment. (E) Proportion of ancestral alleles at hominin-diagnostic sites, in Mezmaiskaya 1 and simulated Ursus arctos ancient DNA. 
A

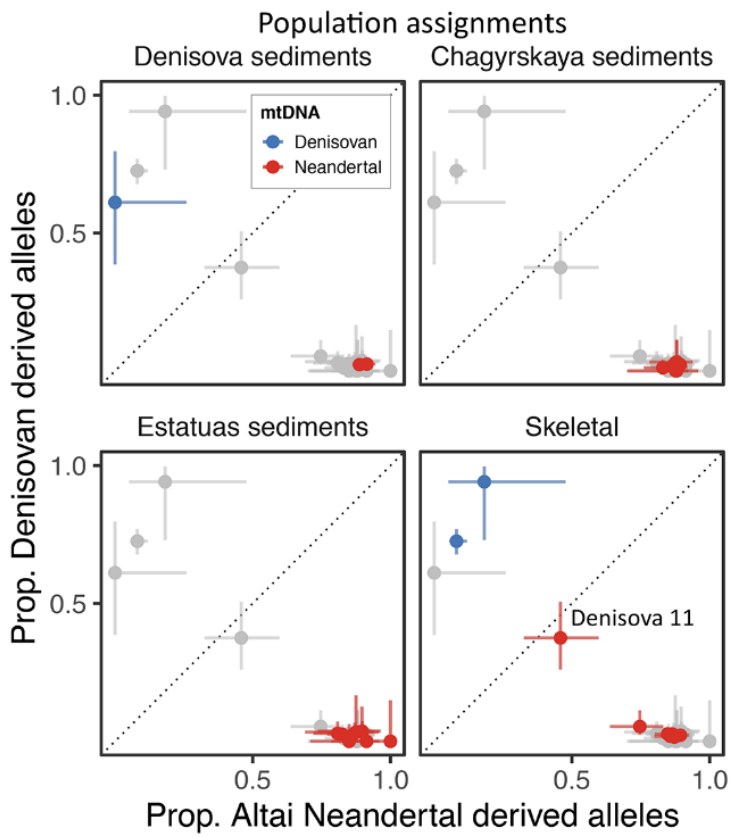

C

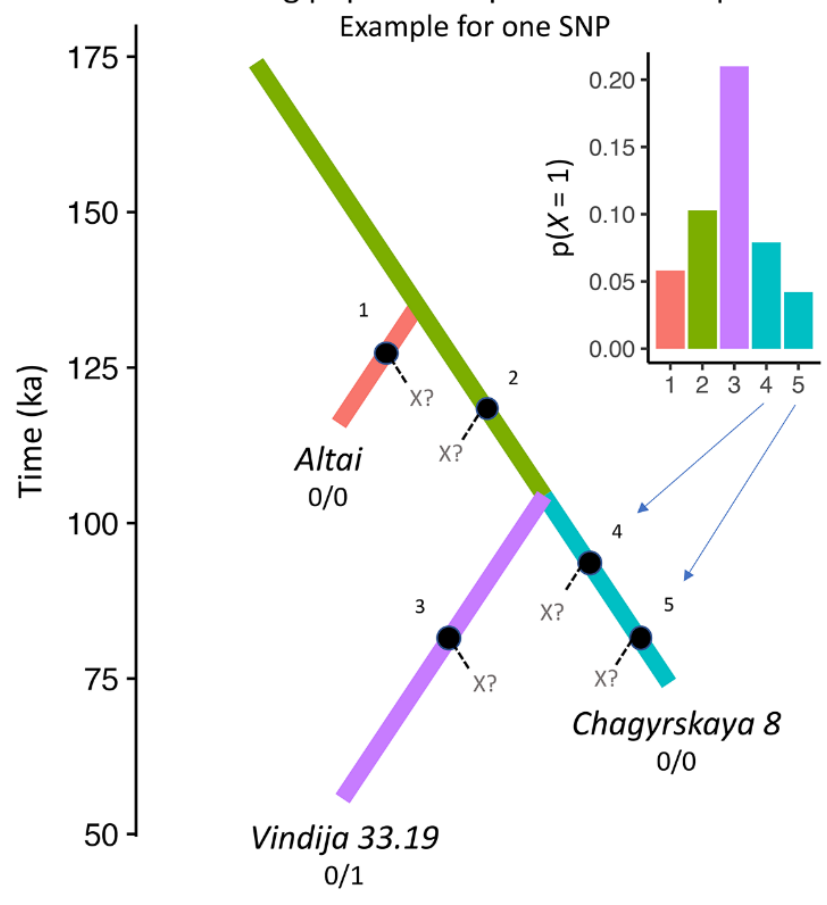

B
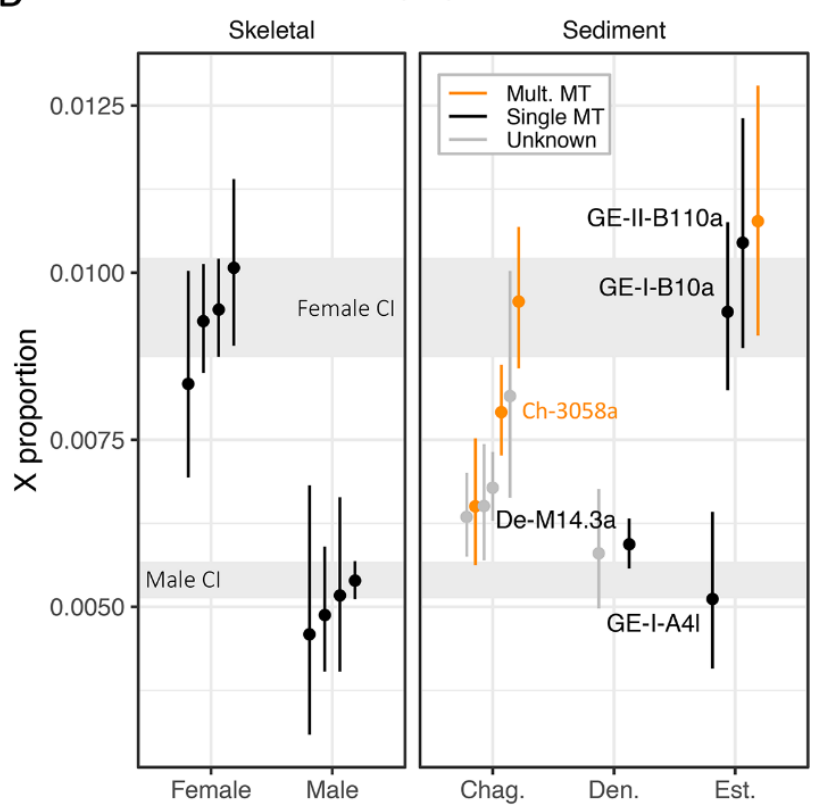

D
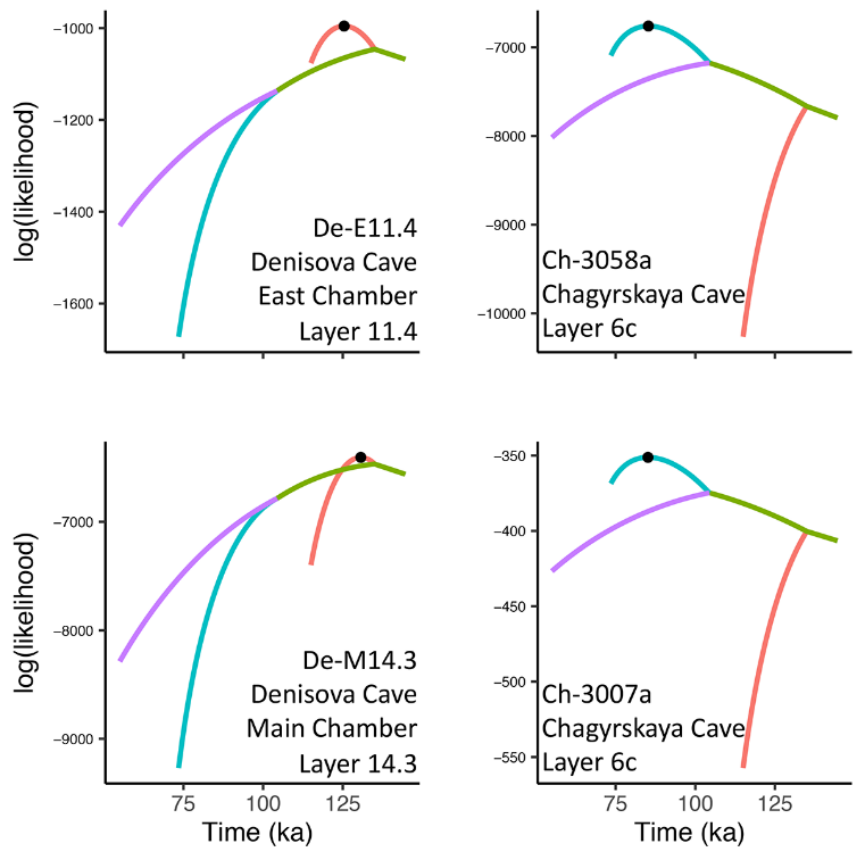

Fig. 4. Sediment nuclear DNA first results. (A) Neanderthal versus Denisovan alleles place sediment (top row and bottom left) and skeletal (bottom right) samples into broad population groups. All samples shown in grey in all plots. $\mathrm{Cl}$ are 95\% binomial confidence intervals. (B) X-autosome proportions for skeletal and sediment samples. $\mathrm{Cl}$ are 95\% binomial confidence intervals. Male and Female $\mathrm{Cl}$ bands (grey) denote male and female skeletal samples with narrowest $\mathrm{Cl}$, respectively. Evidence of single (black) or multiple (orange) mtDNA haplotypes taken from table S3. All samples labeled in fig. S17. (C) Modeling $p(X=1)$, the probability that a sediment sample $X$ carries a derived allele at an example SNP in the genome, where Vindija is heterozygous $(0 / 1)$ and Chagyrskaya and Altai are homozygous ancestral $(0 / 0) . p(X=1)$ depends on the time at which sample $X$ diverges from the Neanderthal phylogeny (black dots are hypothetical split times; inset shows $p(X=1)$ for each split time). (D) Likelihood surfaces (lines) and maximum likelihood estimates of branching times for four sediment samples (black dots). 
A

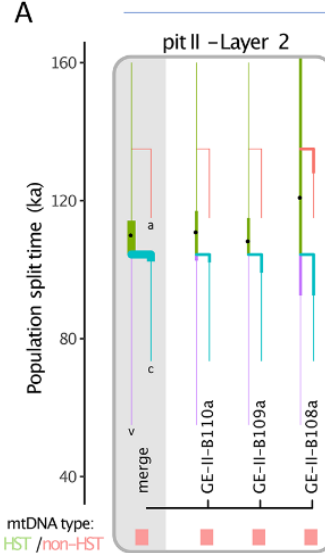

pit I - Layer 2

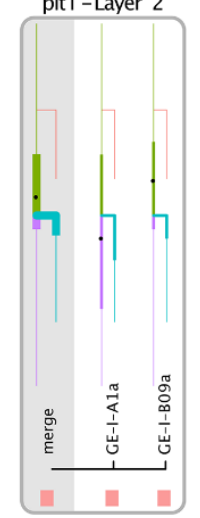

pit
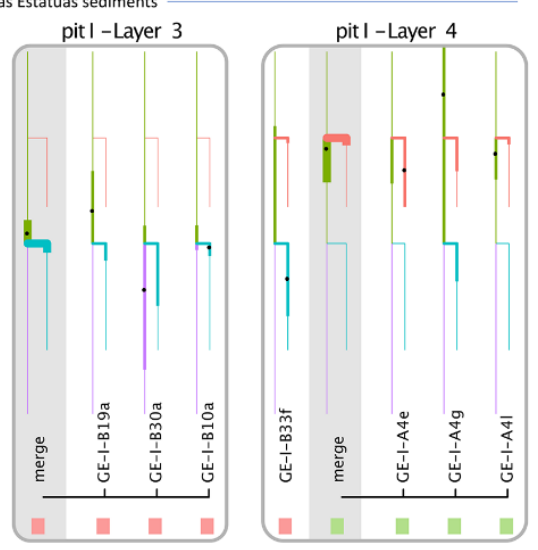

B

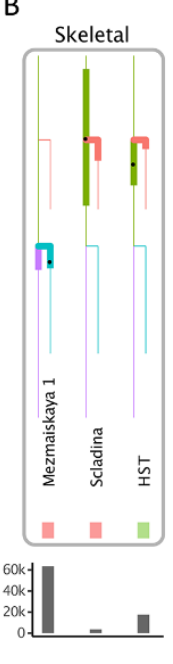

C

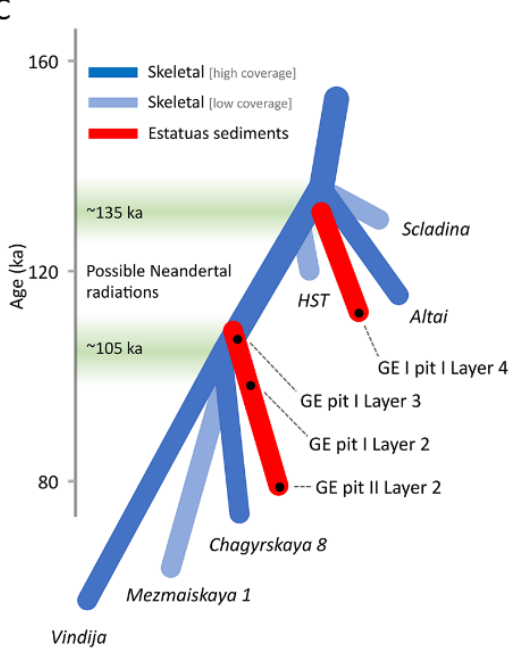

Fig. 5. Sediment samples placed on Neanderthal phylogeny. (A) Population split estimates for sediments across four layers of Galería de las Estatuas (black dot is maximum likelihood estimate; thick lines are 95\% block bootstrap $\mathrm{Cl}$; Cl clipped at 160 ka for GE-II-B108a and GE-I-A4g), plotted on Neanderthal population tree, with Vindija 33.19 (v), Chagyrskaya 8 (c) and the Altai Neanderthal (a). For each layer, sub-samples were merged to produce per-layer estimates (grey blocks, "merge"). For pit I/Layer 4, only samples with HST-like mtDNA (green squares) were merged. Bottom row shows estimated number of Neanderthal SNPs used in the branch-time analysis (grey) and modern human contamination estimates (blue). (B) Same, for three skeletal samples. For Mezmaiskaya 1, a 1x coverage genome was down-sampled to $\sim 60 \mathrm{k}$ informative reads. (C) Clustered split times in the Neanderthal phylogeny suggest successive radiations of Neanderthal populations approximately 105 and 135 thousand years ago. 